\title{
Trapped in the Quagmire of Misery: Exorcizing Neurosis of Violence in Mia Couto’s Voices Made Night and Bessie Head's Tales of Tenderness and Power
}

\author{
Niyi Akingbe \\ Federal University Oye-Ekiti, Ekiti State, Nigeria
}

\begin{abstract}
Arguably, Africa comparatively remains a huge repository of misery and violence in the 21st-century, an attempt to account for narratives within the context of political development has posed an irresistible challenge and a disturbing necessity for Mia Couto in Voices Made Night (1990) and Bessie Head in Tales of Tenderness and Power (1989). The position of Couto as a white Mozambican writer and Head as an exiled coloured South African writer, living in her adopted country of Botswana, provides them with privileged neutrality from which to view the effect of the admixture of grinding poverty and violence as they ravage the landscapes of these countries. While Couto does not fail to incorporate the significance of power struggle between FRELIMO (Front for the Liberation of Mozambique) and RENAMO (Mozambique National Resistance) in the Voices Made Night, Head's articulation of the complex manipulation of power becomes a resource for constructing a discourse of nationalism in Tales of Tenderness and Power. The paper intends to focus on the correlation between power and economic development in these anthologies. The paper will further examine how political power impacts on the socio-economic well being of the local folks in the Couto's Mozambique and Head's South Africa.
\end{abstract}

Keywords: quagmire of misery, neurosis of violence, Mozambique, South Africa, poverty, Mia Couto, Bessie Head

\section{Introduction}

Mia Couto’s Voices Made Night (1990) and Bessie Head's Tales of Tenderness and Power (1989) are anthologies of short stories grounded in the relics of the Mozambican and South African past. Although, the power of the present to unearth the past strewn with misery and violence is problematized by the mismanagement of political power in post-colonial Mozambique and apartheid South Africa. It is a past mediated by the memory which tasks both Couto and Head's imaginative conception of the dark periods in the Mozambican and South African histories. Faced with the indisputable recognition of the effect of mismanagement of power on the downtrodden masses of these two countries during these periods, Couto and Head are of the realisation that memory abhors the romanticism of amnesia in whatever disguise, most especially when it beckons on the re-telling in details of a political violence which threatened and almost destroyed their nations in the recent past. In this regard, Soyinka's (1999) examination of the role of memory seems apt here "[t]he role of memory, of ancient precedents of current criminality, obviously governs our

Niyi Akingbe, Ph.D., associate professor of Comparative Literature, Department of English and Literary Studies, Federal University Oye-Ekiti. 
responses to the immediate and often more savage assaults on our humanity, and to the strategies for remedial action” (p. 20). Couto employs in his anthology of stories, the framework of memory which is deeply shaped by the surrealistic symbolic forms in navigating the RENAMO's backlash against the FRELIMO's political domination and policies which degenerated into the civil war and its effect on the rural folks in the postcolonial Mozambique. The history of postcolonial Mozambique is privileged as the discursive arena in the anthology for evaluating the relationship between economic development and political community. The deployment of memory and mythology for the narration of the Mozambican social and political history in Couto's literary oeuvre has been explained in the words of Goncalves (2009):

Couto's work draws heavily on the speech patterns of Mozambicans and on themes of traditional oral story telling. His narrative subjects and traditional myths join everyday life events of post war life in Mozambique. Couto blurs boundaries between the living and the dead, the individual and the community, and men and women. (p. 1)

If memory plays a significant role in the contextualisation of the Mozambican political tension and violence in Voices Made Night, its significance is effusively appropriated as a narrative trope in engaging the complex social relations among the black folks in the apartheid South Africa. In Tales of Tenderness and power, Head dwells on the longstanding poverty exacerbated by racial tension between the black and white in the apartheid South Africa to articulate a poignant thematic preoccupation. Violence as the resultant effect of this tension is much felt in the black townships adjourning Johannesburg and Soweto which witnessed a concomitant increase in blood-letting during the apartheid. Commenting on what usually necessitate the justification for the perpetration of violence by a group against the other, Brennan (1993) posits that the narrativization of identity is grounded in spatial terms:

The need to separate subject from object, us from them—and in this case, to turn "them” into "objects". In order to accomplish this, a "foundation fantasy" must be constructed in such a way as to reinforce the needs of the ego to comprehend itself as the "locus of active agency". (p. 11)

More striking is Head's unabashed depiction of violence in her Tales of Tenderness and Power, it is demonised as the most debilitating factor militating against human development in the postcolonial Africa. By taken up the intersection of misery and violence in their anthologies, Couto and Head have utilised literature according to Edward (1990) Said, to articulate:

A crucial role in the establishment of a national cultural heritage, in the reinstatement of native idioms, in the re-imagining and re-figuring of local histories, geographies, communities. As such... literature not only mobilized active resistance to incursions from the outside, but also contributed massively as the shaper, creator, agent of illumination within the realm of the colonised. (pp. 1-2)

Head's assessment of the balance of power between the races dramatizes the black township's violence within the ambit of narrative fiction. But blending art and politics in her description of the uncanny circumstances generated by this social tension between the two races, Head constantly avoids a racial identification in these stories. Perhaps this distance is anchored on her racial status which is neither white nor black but coloured. Mosieleng (2004) contends that Head's racial ambivalence is orchestrated by her fragmented personal background "which was fundamentally non-African in many respects, three of which may be singled out: language, companionship, and art” (p. 57).

Historical consciousness grounded in memory has been identified in this paper as an important factor in the shaping of the reactions of both Couto and Head to the socio-political situations in Mozambique and South 
Africa. The import of history is particularly amplified in this paper by these writers whose commitment to the emergence of new geopolitical realities is directed toward the tasks of nation-building, emancipation and the enhancement of national consciousness. The socio-political consciousness of literature in African society is inevitable for several reasons: It is ingrained in the "traditional literatures" of the countries in the continent; Africa's peculiar history has made the delineation of social issues crucial to the proper working of any profession or discipline; many writers espouse ideologies such as Marxism or socialism which make the advocacy of social change an article of faith; Africa's contemporary predicament is such that arguably, no one with the sensitivity and insight of a "true" artist can be immune to engaging with it in his work. As Agovi (1995) claims, literature or artistic forms become the nerve centre of a network of complementary institutions which are "integrated into the state machinery by virtue of their pursuit of similar or related goals and ideals" (p. 10). Such institutions are made to pay allegiance to a common body of ideas and values that give rise to a sense of humanism in African society.

The paper is focused on these three planks: Firstly, it revolves around the crucial issues of society, literature, and memory. It suggests that there are certain identifiable interconnections between art, politics, and economic well-being of a particular state; Secondly, in focusing on the interconnection between economic and violence in the two anthologies over a particular period of time, the paper raises questions regarding how contending social forces arise as a result of socio-economic and political difficulties, and seeks to discover the precise nature of the literary depiction of social problems within the context of other forms of social intervention; Finally, the paper will conclusively aim at assessing the significance of literary insight in delineating social issues and the efficacy of the manner in which it proposes solutions to them in the anthologies.

\section{Foregrounding the Intersection of Misery and Violence on New Historicism}

Given its status as a critical mode which emphasises "the relationship between a text and the society" that produces it, the literary theory known as New Historicism has been chosen as the framework for this paper. It is a theory which interrogates the assumptions and attitudes governing how events are seen differently by the author and individual readers of a literary text. It relates a text to other texts produced at the same period in a given society; thus, literary and political connections can be drawn between the aesthetic elements embedded in the text, and the cultural realities that obtain in such a society (Tyson, 1999, p. 288). Within the ambit of New Historicism, the subject matter and thematic concerns of the texts under focus will be analysed with a view to drawing out these connections and discussing their significance within the analytical concerns of the paper. New Historicism is pre-occupied with the examination of literary texts from the perspective of their being embedded within the social and economic circumstances in which they are produced and consumed. For New Historicists, these circumstances are not stable in themselves and are susceptible to be re-written and transformed; from this perspective, literary texts are part of a larger circulation of social energies, both products of and influences on a particular culture or ideology.

New Historicism proffers an eclectic approach to literary study, as such, it incorporates many aspects of other critical viewpoints, even if it does not agree with them in totality. For example, it obtains from New Criticism the approach of seeking the interconnectedness that underlies any work of art (Selden, 1989, p. 192). It shares with Reader-Response theory, the view that a work of literature can impart different meanings to different readers (Booker, 1996, p. 137). From Postmodernism, New Historicism appropriates the critical doctrines of discontinuity, eclecticism, heterogeneity, and decentred authority in narratives. It rejects Derrida's 
notions of the interface of language and text, but puts forward its own concept of the interconnection between culture and society. Like psychoanalysis, the theory explores the notion of power struggles and similarly advocates that power produces individual subjects. New Historicism shares with Marxism the notion that literature tells the story of the past. However, while Marxism advocates the complete liberation of the oppressed as a critical objective, New Historicism returns to the stories in the texts to find out how they affect society. These extensive borrowings from other theories have given it a flexibility that enables it to adapt the analytical tools and perspectives of other theories to suit its own purposes.

The overt concern of "New Historicism with power relations" among social classes in a given society makes it particularly appropriate to this study. Influenced by Michel Foucault, new historicist critics are interested in "concerns of power, authority and subversion at work in texts" (Carlson, 1993, p. 526). Selden (1989) also emphasises this pursuit when he states that "the New Historicists believe that Foucault's work opens the way to new and non-truth oriented forms of historicist study of texts” (p. 161). New Historicism's concept of history is diametrically at variance with those of the old historicists of earlier periods. For these predecessors, "History is a homogenous and stable pattern of facts and events which can be used as background to the literature of an era" (Abrams, 1981, p. 184). For the New Historicists, however, history is actually: A dynamic, unstable interplay among discourses, the meanings of which the historian can try to analyse, though the analysis will always be incomplete, accounting for only a part of the historical picture (Tyson, 1999, p. 287).

As is typical of New Historicism, Voices Made Night and Tales of Tenderness and Power's interpenetration of Mozambican and South African political histories is patently relative and involves a negotiation of meanings between competing groups rather than its imposition by a dominant group. In conformity with New Historicism, Couto and Head recognise in their anthologies that history is the history of the present, always in the making, and radically open to transformation and rewriting, rather than being monumental and closed. Just like New Historicists, the writers argue that any "knowledge" of the past is necessarily mediated by texts of different kinds. Hence, there can be no knowledge of the past without interpretation; the "facts" of history need to be read just like any other text. White (1978) suggests that knowledge of the past is determined by particular narrative configurations or stories as he states:

Histories ought never to be read as unambiguous signs of the events they report, but rather as symbolic structures, extended metaphors, that 'liken' events reported in them to some form with which we have already become familiar, in our literary culture... By the very constitution of a set of events in such a way as to make a comprehensive story out of them, the historian charges those events with the symbolic significance of a comprehensive plot structure. (pp. 91-92)

Since Couto and Head are imbued with the conviction that social conflict is inescapable, as such, they focus their anthologies upon the intersection of misery and violence in Mozambique during the civil war and South Africa during the apartheid regime. They perceive their societies as being made up of many different social classes and interest groups with differing and often competing interests. Given the unequal distribution of power in most human societies however, many of these groups are unable to properly articulate their concerns or have them incorporated into the grand narratives (including literature) that societies create about themselves in order to project a distinct identity. Indeed, it is the class that is dominant at any one time in a given society that is able to impose its perspectives upon the others in such a way that it is normalized and accepted as the worldview of everyone, even when it is only representative of only a group. Thus, most societies have adopted an "us versus them" approach to creating a group identity—-the Greeks divided the world into civilisation and 
barbarians, placing themselves in the former category, and everyone else in the latter category; monarchies propounded the divine right of kings as the natural order of things, rather than as an attempt to secure their power and influence; both Christians and Muslims demonise each other as "infidels" and other religions as "idol worship" in order to secure the loyalty of their own followers rather than because those other faiths are intrinsically evil; autocratic rulers throughout history have equated opposition to their rule with treason, regardless of whether such opposition is justifiable or not.

Suffice it to say that Couto and Head have argued in their anthologies that any "knowledge" of the past is necessarily mediated by texts, or to put it differently, that history is in many respects textual. A number of major consequences follow from this assertion. In the first place, there can be no knowledge of the past without interpretation. Just as history texts need to be read, so do the "facts" of history. From a new historical perspective, any reading of a literary text is a question of negotiation: a negotiation between text and reader within the context of history or histories that cannot be closed or finalised. Consequently, narratives in the Voices Made Night and Tales of Tenderness and Power are to be understood in terms of negotiation rather than in the conventional sense of a pure act of untrammelled creation. For example, Perraudin (2005) comments on this negotiation between two opposing groups in a society and draws attention to what he perceives as the potential cause of political tension in the postcolonial African countries:

The acts of violence seem inevitably confined to a highly political and public sphere. The driving motivation behind these acts of torture, excorporations, and rape seems to stem from a desire to weaken the ability of the other to assert himself or herself within a realm of power that is in the process of being contested. (p. 73)

This implies negotiations which are a subtle, network of trades and trade-offs, and a jostling of competing representations. On this note, both Couto and Head have demonstrated in their anthologies, that work of art is the product of negotiation with a complex, communally-shared repertoire of conventions, and the institutions and practices of society.

\section{Claiming the Burden of Exclusion}

From a memory perspective, Mozambique is depicted as a politico-historical landscape in Voices Made Night, whose first story begins with "The Fire". Operating within a defined geo-political discourse which embraces an allegory of the mismanagement of the Mozambican postcolonial opportunities by its ruling elite, "The Fire" narrates a story of an aged couple living on the economic fringes of the rural Mozambique. At the critical phase of their lives in which they are now living alone and doing domestic chores by themselves, the old man became terribly apprehensive that the wife might die before him. To lessen this burden, the old man bought a spade and started digging the wife's grave. The wife's reaction to this bizarre act is a confounding bewilderment, which provides the reader an opportunity of viewing the adversarial relationship between the couple. However, the man became very sick and died due to the exhaustion he suffered from digging of the grave. He ironically ended being buried in the grave he dug for his wife.

What becomes apparently revealed in "The Fire" is an indictment of the FRELIMO's awkward political policies grounded on the Marxist-Leninist framework, which does not accommodate the aspirations of the various Mozambican ethnic groups and the development of the indigenous traditional practices. Unfortunately, these policies fragmented the post-colonial Mozambican society rather than uniting it, and plans for national development become bureaucratized along the European standards. After waging a debilitating warfare against 
the Portuguese colonization for ten years, Mozambique attained independence in 1975. Nevertheless, FRELIMO's tragic adventure into the political goose chase is inaugurated with a false start: It started ruling by proclaiming Mozambique a one-party state without conducting any elections. This FRELIMO's Stalinist appropriation of power forced the RENAMO to take to a guerrilla warfare which lasted decades with colossal casualties in human and infrastructure.

Couto's allegorical representation of the FRELIMO's adoption of the Marxist-Leninst policies for the governance of Mozambique as exemplified in “The Fire” has been commented upon by Goncalves (2009):

The policies that FRELIMO has implemented in the country are a grave that is supposed to bury the old; but as in the Couto's story if the old way does not die, then it has to be killed. The "digging" of these policies creates the need for the grave of the system itself. (p. 26)

The hypocrisy of the FRELIMO's over subscription to the Marxist-Leninist propaganda is further Criticised by Couto (1990) in the dream of the old woman, where the falsehood of these policies is eloquently critiqued:

When the moon began to light up the trees in the wood, she leant back and fell asleep. She dreamed of times far away from there: her children were present, the dead ones and those still alive, the machamba was full of crops, her eyes slid over the green of it all. There was the old man in the middle, with his tie on, telling stories, lies for the most part. (pp. 4-5)

FRELIMO is typified as the old man in "The Fire" and its adoption of the Marxist-Leninist propaganda in the shaping of the Mozambican national development policies is likened in the dream to a falsehood due to its ineffectiveness in moving the Mozambican economy forward.

A biting satire on the FRELIMO's political philosophy is further drawn from mismanagement of the flood crisis in "The Tale of the Two Who Returned From the Dead". It is a narrative which examines the plight of Luis Fernando and Anibal Mucavel who suddenly returned to the village, after they had been given up for dead following the devastating floods which swept away scores of people and submerged their village. The duo was denied food and relief materials which required the intervention of the FRELIMO regional authority to resolve. In reconstructing the Mozambican past within the context of New Historicism discourse, Couto (1990) essentially employs a deft allegorical gambit in examining the FRELIMO’s fetishization of Marxist ideological leanings as portrayed in the following passage:

The official arrived on the scene. He was a tubby man, his belly inquisitive, peeping out of his tunic...

“Look: they‘ve sent us supplies. Clothes, blankets, sheets of zinc, a lot of things. But you two weren’t included in the estimate".

Anibal became agitated when he heard they had been excluded:

“What do you mean not included? Do you strike people off just like that?’ But you have died. I don’t even know how you came to be here”. "What do you mean died? Don’t you believe we are alive?” "Maybe, I'm not sure any more. But this business of being alive and not alive had best be discussed with the other comrades”. (pp. 71-76)

The passage reveals FRELIMO's bureaucratized approach to the treatment of national issues in the postcolonial Mozambique which leaves a lot to be desired, and has been polemically criticised in the words of Goncalves (2009):

Marxism, introduced to the country by FRELIMO’s leadership, provided the universal language of class capable of denying the ethnic and cultural diversity of Mozambique. This political philosophy gave the tools for the conception of 
an ideal, yet fabricated a country where the workers allowed FRELIMO to exercise its power in their name against the enemies of the people. The post-Independence project of FRELIMO took seriously the transition to socialism. The political elite of the country was influenced by European principles and failed to look within for the answers to the absolute question of what it means to be Mozambican. (p. 35)

Correspondingly, placing emphasis upon the imbalance of power between the majority blacks and minority whites, recalls an inscription of political tension in the apartheid South Africa's trajectory of violence as Head's Tales of Tenderness and Power exemplifies. This tension is grounded in "Oranges and Lemons”, a story which anxiously expresses the effect of unmitigated violence perpetrated by the black gangsters, on the black folks during the apartheid South Africa. The dimension of crime, bloodshed, rape and maiming in these townships occur with frightening frequency. Head (1989) offers readers insightful penetration into lives of the residents who are cramped in the identical small match-box houses; mostly in and out of poorly-paid employment, and are generally: "helplessly trapped in one long dark nightmare without end". The few who "resisted the evil... were swiftly eliminated..." (p. 19). The helplessness of the black folks to ward off these wanton killings, conveniently, made death very cheap in these townships. The story reflects a degeneration of humanity into bestiality caused by the political ills of apartheid.

We may without difficulty surmise that Head's rendering of the narrative of "Oranges and Lemons" in a seamless intertextuality with references to poverty and the apartheid government's unwillingness to criminalize gangsterism in the black townships, intends to indict the white minority-run South Africa apartheid regime. Power and its attendant problematic thus privilege the enabling discursive treatment of the glorification of violence by the subterranean rival gangs, whose profiles are trenchantly depicted in grotesque comic details of the narrative. It is a depiction which confirms Head's familiarity with a blow-by-blow fluidity of crime occurrences in these run-down neighbourhoods. The objectification of pain borne by the victims of these black townships' violence adequately provides a site for the reading of power articulation in the narrative. It is an articulation Scarry (1985) has remarkably dealt with in her book, The Body in Pain:

The de-objectifying of the objects, the unmaking of the made, is a process externalizing the way in which the person's pain causes his world to disintegrate; and, at the same time, the disintegration of the world is here [...] made the direct cause of the pain. (p. 41)

We can conclude from this standpoint that Head's characters in "Oranges and Lemons" in the likes of Old Ben, Jimmy Motsisi and Mary are victims whose bodies borne the weal of pain inflicted in the power-play manipulated by the rival gang leaders: "Hot Sparks" Phalane and "Big Brain Mazooki" alongside the witchy-bitchy Daphne Matsulaka whose paranoia get expressed in befuddled aspirations. Black on—black violence in the narrative invokes a power discourse which depicts residents of the black-ownships in "Oranges and Lemons" as casualties of a cul-de-sac racialized society. As such, they could only access the limited crumbs of social privileges available in the black townships, and could not rise above the apartheid colour limitations. By vocalizing the magnitude of this black township violence, Head has subtly mounted pressure on the apartheid regime to wake up to its legitimate responsibility of enacting social policies that will remarkably ameliorate this tiring macabre.

If the South Africa's violence vividly captured in Head's “Oranges and Lemons” seems sporadic and isolated, violence in the Couto's Mozambique is apocalyptic, horrendous, and total. The process of rewriting the Mozambican tragic civil war facilitates the uncovering of acts of violence, whose overwhelming effect on 
the masses is dauntingly scandalized by Couto in "The Day Mabata-bata Exploded". This is a fast-moving sombre narrative of the misfortune of an orphan, Azarias who constantly trudges a wooded valley set against the backdrop of a nameless village (in "The Day Mabata-bata Exploded"), from dawn to dusk tending the herd of cattle. However, one day while shepherding the herd, the prized-cattle otherwise called Mabata-bata stumbled upon a land mine which must have been planted by the RENAMO rebels and got blown into smithereens. In coming to terms with the understanding that his Uncle Raul would flog him for been careless, Azarias decided to hide himself in the valley as to stay away from home. But in heeding the call of his grandmother and Raul to come out of his hiding, he stepped on a mine which killed him instantly. The narrative heightens effect of the Mozambican war caused by the rivalry between FRELIMO and RENAMO which left in its wake army of maimed, pauperized and traumatized rural dwellers as its casualties. By evincing episodic narrative technique in "The Day Mabata-bata Exploded", Couto is focusing attention on the plight of Azarias who became an orphan at a tender age and became a cowherd to his cruel uncle, Raul. This attention is further deepened by Couto's evaluation of Azaria's inability to access a formal education in the narrative due to poverty, which embeds a powerful metaphor for the interconnectedness of violence as harbinger of war and deprivation. For Couto, in effect, violence in "The Day Mabata-bata Exploded" problematizes the spate of political upheavals in the postcolonial Africa, whose narrations take pre-eminence over other national issues (Cazenave, 2005, p. 60). In explicating the symbolism of this story, Couto is at pain to stress that a society at war can never make any economic headway. Azaria typifies the collective Mozambican masses whose voices have been submerged in the bedlam of political schism, and whose lives have been disrupted by the ideological differences between FRELIMO and RENAMO which degenerated into civil war of 30 May 1977 to 4 October 1992.

It is interesting to note that the struggle for power occupies a prominent place in the African postcolonial discourses, but not limited to the Mozambican literary discourse. Oseghae (2004) while cautioning against inordinate struggle for power in postcolonial Africa posits that:

[I]ssues of contested identity, autonomy, citizenship, equity, power sharing and rights loomed larger than ever before in postcolonial Africa (emphasis mine), thanks to the contradictions of globalisation, democratization, liberalization and other simultaneous economic and social processes that gave vent and legitimacy to non-state and anti-state claims and demands. (p. 10)

Inordinate struggle for power highlights a discourse which Head has also subjected to a critical evaluation in "A Power Struggle": a story of bitter political rivalry between two royalties of the Tlabina clan, Davhana, and Baeli. The narrative focuses on the displacement of Davhana the throne's heir apparent, by his younger brother Baeli, who crowned himself in his stead afterwards through sheer brigandage. Interestingly the narrative condemns inordinate ambition among politicians, in their blind pursuit of power in the postcolonial Africa. Although, the story revolves around a melange of narrative styles, from oral narrative and fictional narrative anchored on a political anecdote which has its setting in the pre-colonial South Africa.

Its import tellingly reflects a troublesome political trajectory in the pre-colonial Africa which got extended to the postcolonial Africa, where criminals and individuals of questionable characters have often emerged as members of the political elite of most African countries. Baeli's usurpation of power through might rather than the people's will, led to the political ruination of the Tlabina clan. This communal ruination reflects Soyinka's (1999) submission on the violent crime perpetrated by the African rulers on their subjects " $[t]$ he crimes that the 
African continent commits against her kind are of a dimension and, unfortunately, of a nature that appears to constantly provoke memories of the historic wrongs inflicted on that continent by others” (p. 19). By exploring the way in which power is deviously pursued and aggressively hijacked by Baeli, Head ostensibly tends to demonstrate that power is often violently acquired in Africa through armed insurrection rather than by democratic means.

If the discourse of power and its acquisition process in the pre-colonial Africa foregrounds the thematic preoccupation of "A Power Struggle", its deployment as a weapon for hounding the real and imagined enemies constitute its dialectic in "The General". It is a narrative which anatomizes power and its intoxication in a nameless, postcolonial Southern African country, where a charismatic personality was elected on the basis of brilliance and patriotism. In retrospect, these twin attributes of the President have been elliptically alluded to by Head (1989) in the narrative "[T]hings were not so bad in the beginning. The President had charm and his intellectual brilliance was recognised throughout the whole world. He was completely objective and that was his charm" (p. 102). Characteristic of most leaders in the postcolonial African states, the nameless president in the narrative soon become a despot with egocentric and dictatorial credentials. His dictatorial proclivity manifests in the incarceration of scores of brilliant young politicians and intellectuals who were railroaded into jail and others forced into hasty exile. This madness continued unabated until a coup forced the president out of power. Inherent power dialogic embedded in "The General”' has been appropriated by Head to highlight consequences of political tyranny and dictatorship in the postcolonial Africa.

\section{Conclusions}

The paper has articulated how memory has been appropriated to untangle a complex web of misery and violence which permeated the narratives of Mia Couto's Voices Made Night and Bessie Head's Tales of Tenderness and Power. Just as New Historicism does not consider art (images and narratives) as products to be merely contemplated for their aesthetic content, the paper has argued that stories in the anthologies fittingly operate as sites of "socio-political workshop" where political issues, economic anxieties, social struggles, problems, hopes and aspirations are addressed by the two writers.

The paper has subjected the literary interpretations of the political tension between FRELIMO/RENAMO in Mozambique and the black township's violence in the apartheid South Africa within the historical epochs that produced the texts, which have invariably influenced the issues raised in them. Couto and Head's reliance on memory in the anthologies becomes a means of negotiating the Mozambican and South African politics and societies in the paper. To this end, critical attention consequently shifts from the authors, the canons and the organic texts to the study of the forms and flows of power. In conclusion, memory facilitates in the texts, sites for the negotiation, authorisation, interrogation, and recuperation of the dialogic between the adversarial parties, between the ruler and the ruled.

\section{References}

Abrams, M. H. (1981). A glossary of literary terms. New York: Holt, Rinehart and Winston.

Agovi, K. (1995). A king is not above insult: The politics of good governance in Nzema Avudwene festival songs. In F. Graham,

\& L. Gunner (Eds.), Power, marginality and African oral literature (pp. 47-61). Cambridge: Cambridge University Press. Booker, K. M. (1996). A practical introduction to literary theory and criticism. White Plains: Longman.

Brennan, T. (1993). History after Lacan. London and New York: Routledge. 
Carlson, M. (1993). Theories of the theatre: A historical and cultural survey from the Greeks to the present (Expanded Ed.). Ithaca, NY: Cornell University Press.

Cazenave, O. (2005). Writing the child, youth, and violence into the Francophone novel from Sub-Saharan Africa: The impact of age and gender. Research in African Literatures, 36(2), 59-71.

Couto, M. (1990). Voices made night. England: Heinemann Education Limited.

Goncalves, L. (2009). Mia Couto and Mozambique: The renegotiation of the national narrative and identity in an African nation (Ph.D. Thesis, Carolina: University of North Carolina).

Head, B. (1989). Tales of tenderness and power. England: Heinemann Education Limited.

Mosieleng, P. (2004). Conditions of exile and the negation of commitment: A biographical study of Bessie Head. In I. Human (Ed.), Emerging perspectives on Bessie Head (pp. 105-125). Trenton, NJ and Asmara, Eritrea: Africa World Press, Inc..

Oseghae, E. E. (2004). Federalism and the management of diversity in Africa. Identity, Culture and Politics, 5(1-2), 164.

Perraudin, P. (2005). From a "large morsel of meat" to "passwords-in-flesh": Resistance through representation of the tortured body in Labou Tansi’s La vie et demie. Research in African Literatures, 36(2), 72-84.

Said, E. (1990). Figures, configurations, transfigurations. Race and Class, 32(1), 1-16.

Scarry, E. (1985). The body in pain: The making and unmaking of the world. New York: Oxford University Press.

Selden, R. (1989). Practicing theory and reading literature: An introduction. New York: Harvester Wheatsheaf.

Soyinka, W. (1999). The burden of memory, the muse of forgiveness. New York: Oxford University Press.

Tyson, L. (1999). Critical theory today. New York: Garland Publishing, Inc..

White, H. (1978). The historical text as literary artifact: Essays in cultural criticism. Baltimore: John Hopkins University Press. 